\title{
Clinical characteristics of antibody-mediated rejections with C1q- binding and without C1-binding donor-specific antibodies
}

\author{
Chung Hee Baek, Hyosang Kim, Su-Kil Park
}

Department of Internal Medicine-Nephrology, Asan Medical Center, University of Ulsan College of Medicine, Seoul, Korea

Background: Donor-specific antibodies (DSAs) increase the risk of rejection and graft loss in kidney transplant (KT) recipients. However, all DSAs are not clinically relevant. Therefore, the C1q assay has been recently used to detect complement-binding DSAs, but its clinical meaning and usefulness should be investigated more.

Methods: This paper studied the clinical characteristics of $\mathrm{KT}$ recipients who had antibody-mediated rejection with C1q-binding and without C1q-binding DSA. Among the 5,097 patients who received KT in a center between 2000 and 2020, 21 had C1q assay test results with DSA when antibody-mediated rejection was diagnosed. Clinical and pathologic data were compared between 16 and five patients with C1q-binding DSA (C1q[+] DSA group) and without C1q-binding DSA (C1q[-] DSA group), respectively.

Results: All patients in both groups had human leukocyte antigen (HLA) class II. The peak mean fluorescence intensity of HLA class II DSA was significantly higher in the C1q(+) compared with the C1q(-) DSA group $(13,744 \pm 5,512$ vs. 6,378 $\pm 3,039 ; P=0.011)$. No significant difference in pathologic findings was noted between the two groups. However, no patient in the C1q(-) DSA group showed a peritubular capillary C4d stain score of $\geq 2$, although a significant difference between the two groups was not shown $(37.5 \%$ vs. $0 \%, P=0.262)$. Moreover, the $\mathrm{C} 1 \mathrm{q}$ test results were changed in the clinical course in two patients in the C1q(-) DSA group who had follow-up C1q test results. Furthermore, graft survival was not significantly different between the two groups $(\mathrm{P}=0.512$ by log-rank test).

Conclusions: Antibody-mediated rejection with $\mathrm{C} 1 \mathrm{q}(+)$ and $\mathrm{C} 1 \mathrm{q}(-)$ DSA may have different clinical characteristics. However, $\mathrm{C} 1 \mathrm{q}$ positivity can change and may overlap in the clinical course. Thus, further studies are necessary to identify underlying mechanisms and clinical application of the C1q assay.

Corresponding author: Chung Hee Baek

E-mail:bch393@naver.com

(c) The Korean Society for Transplantation

This is an Open Access article distributed under the terms of the Creative Commons Attribution Non-Commercial License (http://creativecommons.org/licenses/by-nc/4.0/) which permits unrestricted non-commercial use, distribution, and reproduction in any medium, provided the original work is properly cited. 